\title{
Pembelajaran Audio Visual dalam Mengembangkan Bahasa Anak dalam Membaca Al-Qur'an di TK Rahmat Damai Aceh
}

\author{
Fatmawati \\ Universitas Islam Negeri sunan Kalijaga Yokyakarta \\ Fatwawati5@gmail.com
}

\begin{abstract}
The researcher aims to see the language development of children through visual audio with group B children with a sample taken 37 children consisting of one class B1 totaling 19 people who made 10 children as the control class and 18 more as the experimental class. Research Samples Population is all data that researchers pay attention to in a scope, and a predetermined time. In this study the subject is determined as a source of data relevant to the problem under study to study and draw conclusions. The sample is the population or subject chosen and determined as a source of data or sources of information from the study. Sampling is done by purposive sampling technique which means it is a technique of determining the sample with certain considerations. Based on the results of research students in classes B1 and B2 show that 3 students get high test results, then 22 students get test results with enough categories, and 12 students get the test results in the low category, in knowing and how in the paragraph. A student is called complete learning if he / she scores at least 75 of the ideal grade. In a class students are called complete learning if the class there are at least $85 \%$ of students who complete.
\end{abstract}

Keywords : Audio visual, develops children's language

\begin{abstract}
ABSTRAK.
Peneliti bertujuan untuk melihat perkembangan bahasa anak melalui oudio visual dengan anak kelompok B dengan sampel yang di ambil 37 anak yang terdiri dari satu kelas B1 berjumlah 19 orang yang dijadikan 10 anak sebagai kelas kontrol dan 18 lagi sebagai kelas eksperimen. Populasi adalah seluruh data yang menjadi pwerhatian peneliti dalam suatu ruang lingkup, dan waktu yang sudah ditentukan. Dalam penelitian ini ditentukan subjek sebagai sumber data yang relevan dengan masalah yang diteliti untuk dipelajari dan di tarik kesimpulannya. Sampel merupakan populasi atau subjek yang dipilih dan ditetapkan sebagai sumber data atau sumber informasi dari penelitian. pengambilan sampel dilakukan dengan teknik purposive sampling yang artinya adalah teknik penentuan sampel dengan pertimbangan tertent Berdasarkan hasil penelitian siswa di kelas B1 dan B2 menunjukkan bahwa 3 orang siswa memperoleh hasil tes dengan kategori tinggi, kemudian 22 orang siswa memperoleh hasil tes dengan kategori cukup, dan 12 orang siswa memperoleh hasil tes dengan kategori rendah, dalam mengenal dan cara pada pada ayat. Seorang siswa disebut tuntas belajar bila memperoleh nilai
\end{abstract}


sekurang-kurangnya 75 dari nilai ideal. Dalam suatu kelas siswa disebut tuntas belajar bila kelas tersebut terdapat sekurang-kurangnya $85 \%$ siswa yang tuntas.

Katakunci: Audio visual, mengembangkan bahasa anak

\section{PENDAHULUAN}

Undang- undang Nomor 20 tahun 2003 menyatakan bahwa pendidikan di Indonesia pada umumnya bertujuan untuk menyiapkan generasi penerus yang berkualitas, berketerampilan, dan bertanggung jawab. Dalam mencapai suatu tujuan, upaya yang dapat dilakukan adalah melaui suatu pembelajaran di lembaga pendidikan baik formal, informal, maupun non formal

Pendidikan anak usia dini memegang peranan yang sangat penting dan menentukan bagi perkembangan anak karena pendidikan anak usia dini merupakan fondasi dasar bagi kepribadian anak sehingga anak mendapatkan pembinaan sejak dini. Salah satunya adalah dalam mengembangkan kemampuan bicara, karena bicara berperan penting dalam kehidupan pendidikan anak usia dini sejak lahir sampai dengan usia enam tahun, yang dilakukan melalui pemberian rangsangan pendidikan untuk membantu pertumbuhan dan perkembangan jasmani dan rohani agar anak memiliki kesiapan dalam memasuki pendidikan yang lebih lanjut.

Dengan berbicara, seseorang dapat mengenal dan memahami dirinya, sesama dan juga lingkungan hidupnya. Maka dengan berbicara mengutarakan ide- ide, gagasan pemikiran, hal- hal yang baru maupun yang ingin diketahui melalui bicara. Seperti yang telah dikemukakan oleh Vygosky menurut Astuti dalam Mulyasa, beliau mengemukakan bahwa bicara merupakan sumber penting dalam pendidikan anak usia dini. Di samping itu, Vygosky juga mengemukakan bahwa

pengalaman interaksi sosial merupakan hal yang penting bagi perkembangan proses berpikir anak, sehingga aktivitas mental yang tinggi pada anak dapat dibentuk melalui interaksi dengan orang lain dan lingkungan sekitarnya. Kecerdasan verbal penting bukan hanya untuk suatu keterampilan berkomunikasi melainkan juga kepentingan untuk mengungkapkan pikiran keinginan dan pendapat seseorang. Guru dan orang tua perlu memberikan perhatian terhadap pada masa kemasa (golden age) ini sangat baik untuk mengetahui, memahami dan mengerti perkembangan anak usia dini, akan belajar sesuai apa yang ia ketahui, itu semua tidak lepas dari bicara. Jadi dari itu, untuk meningkatkan bicara pada anak, sebaiknya anak dibiasakan berkomunikasi, berdiskusi dan juga tanyak jawab, bercerita dan juga bernyanyi. Serta memberikan kesempatan pada anak untuk mengungkapkan apa yang belum diketahuinya dan apa yang dirasakan oleh anak. Dengan demikian, segala sesuatu yang pernah diamati dan dialami dapat disimpannya menjadi tanggapan- tanggapan dan pengalaman- pengalaman kemudian diolahnya (berpikir) menjadi suatu pengertian- pengertian. Awal kanak- kanak umumnya merupakan saat 
berkembang pesatnya penguasaaan tugas pokok dalam belajar bicara, yaitu menambah kosa kata, menguasai ucapan kata- kata dan menggabungkan kata- kata menjadi kalimat. Bicara itu sendiri merupakan bentuk bahasa yang menggunakan artikulasi atau kata- kata yang digunakan untuk menyampaikan maksud. Guru dan orang tua haru dapat menciptakan suasana pembelajaran yaang menyenangkan dan bervariasi sehingga menjadikan kegiatan pembelajaran lebih menarik perhatian siswa, itu merupakan suatu tantangan bagi guru dan keluarga, seorang guru harus berusaha untuk mengetahui cara yang tepat untuk menciptakan situasi pembelajaran yang tidak onoton. Sebgai seorang pendidik dalam menyikapi hal, tersebut haruslah dapat bertindak secara bijaksana dalam mengambil keputusan dan juga tindakan. Dan yang tidak kalah penting, guru harus berusaha semaksimal mungkin tentang bagaimana membentuk kepribadian siswa agar menjadi lebih baik sesuai dengan tujuan yang telah diharapkan. Oleh karena itu, pengaruh guru terhadap para siswanya sangat besar dan sangat menentukan untuk mengatasi masalah tersebut agar mampu mengembangkan kemampuan bicara pada anak, maka dalam mengembangkan bicara anak usia dini, hendaknya menggunakan alat peraga, selain berguna untuk memudahkan dalam pengajaran, juga dapat digunakan sebagai alat yang dapat menarik perhatian anak. Menurut Hamalik dalam sukiman, pengunaan media dalam pembelajaran dapat membangkitkan keinginan dan minat baru. Meningkatkan motivasi dan rangsangan kegiatan belajar selain itu, pengunaan media pembelajaran akan sangat membantu proses pembelajaran dan penyampaian informasi (pesan dan isi pelajaran) pada saat itu. Kehadiran media dalam pembelajaran juga dikatakan dapat membantu peningkatan pemahaman peserta didik, penyajian data atau informasi lebih menarik, memudahkan penafsiran data. Jadi dalam hal ini dikatakan bahwa fungsi media adalah sebagai alat bantu dalam kegiatan belajar. Ada dua faktor yang mempengaruhi proses dan hasil belajar, yaitu faktor internal dan faktor eksternal. Salah satu faktor eksternal yaitu lingkungan keluarga.

Keluarga merupakan lingkungan pendidikan yang pertama dan utama. Keluarga merupakan bagian terpenting dalam kehidupan manusia, yang terdiri dari seorang ayah, ibu dan anak. Sedangkan anak merupakan individu yang sedang berkembang dimana mereka sangat memerlukan perhatian khusus dari orang tuanya. Di dalam keluarga anak pertama kali mendapatkan didikan dan bimbingan dari orang tua.

Upaya orang tua dalam mendidik dan membimbing anak merupakan bentuk dari pola pengasuhan orang tua pola asuh orang tua adalah kebiasaan yang dilakukan oleh orang tua dalam memimpin, menjaga, dan membimbing anak yang dilakukan secara konsisten sejak anak lahir hingga remaja dan membentuk perilaku anak sesuai dengan norma dan nilai yang baik dan sesuai dengan kehidupan masyarakat. Pada lingkungannya upaya seorang anak menerima ajaran- ajaran dan mendidikan dari pengaasuhan orang tuanya, yang memberikan pengaaruh terhadap 
perkembangan perilaku anak dalam cara berbahasa sebelum anak mengenal tentang lingkungan sekolah sehingga hal tersebut secaara tidak langsung akan mempengaruhi perilaku tata cara anak dalam berkomunikasi.

Untuk mencapai perkembangan bahasa anak dan keimbang harus dibangun sejak dini, dimana anak usia dini masih mudah untuk menerima setiap stimulus yang diberikan atau sering disebut sebagai periode emas (golden ages). Dimana otak anak mengalami perkembangan yang paling cepat sepanjang sejarah kehidupannya, karena memang otak merupakan kunci utama bagi pembentukan kecerdasan anak. Periode ini hanya berlangsung pada saat anak dalam kandungan hingga usia dini, yaitu 0-6 tahun. Namun, masa bayi dalam kandungan hingga lahir, sampai usia 4 tanun masa- masa yang paling menentukan.

Namun tidak sedikit dari peran orang tua yang melewatkan periode emas anak dengan menjadi dengan berbagai tuntutan belajar dengan mengabaikan konsep dasar anak bermain sembari belajar, orang menginginkan anaknya sukses dalam perkembang, tetapi orang tua membatasi setiap tindakan anak dengan berbagai alasan, orang tua juga menginginkan anaknya mampu berbicara dengan lancar, tapi orang tua mengutamakan sistem pendidikan anarkis dan mengabaikan pendidikan demokratis dimana di balik keinginannya tersebut dan mengikuti sertakan anak dalam setiaptindakan. Dan itu tidak hanya dilakukan oleh lingkungan keluarga saja, bahkan lembaga pendidikan juga terkadang mengabaaikan pendidikan demokratis anak.

Banyak metode yang bisa digunakan untuk mengembangakan bahasa dan anak, tanpa harus mengintimidasi anak. Untuk itu disini penulis menggunakan cara Audio Visual penulis menganggap bahwa mampu memberikan stimulus bagi perkembangan bahasa anak.

Menurut prabowo dalam melani kasim, pembelajaran terpadu merupakan pendekatan belajar mengajar yang melibatkan beberapa bidang studi. pendekatan belajar mengajar ini diharapkan akan memberikan pengalaman yang bermakna kepada anak didik kita. Artinya bermakna disini dikarenakan dalam pembelajaran terpadu diharapkan anak memperoleh pemahaman terhadap konsep- konsep yang mereka pelajari dengan memulai pengalaman langsung dan menghubungkannya dengan konsep lain yang sudah dipahami.

Media pembelajaran Audio Visual dalam proses belajar anak dalam pembelajaran yang akhirnya diharapkan dapat mempertinggi hasil belajar yang dicapai oleh anak. Pemilihan media pembelajaran sangatlah penting. Diperlukan pengetahuan dan keterampilan guru untuk dapat melakukannnya dengan tepat, sehingga media yang diambil sesuai dengan kebutuhan dan perkembangan anak, pada dasarnya pertimbangan untuk memilih suatu media sangatlah sederhana yaitu dapat memenuhi kebutuhan dan tercapainya tujuan yang dingginkan. 


\section{METODE PENELITIAN}

1. Jenis penelitian

Jenis penelitian ini adalah Kuantitatif dengan pendekatan Eksperimen (experimental research). Metode eksperimen adalah kegiatan yang direncanakan dan dilakanakan oleh peneliti untuk mengumpulkan bukti-bukti yang ada ada hubungan dengan hipotesis yaitu penelitian yang dimaksud untuk menyelidiki kemungkinan hubungan sebab- akibat (Causa and effect relationship),.

Tempat penelitian adalah di TK Rahmad Damai Aceh kecamatan peureulak timur kabupaten aceh timur (aceh) di jl. Medan banda aceh dusun sukai damai gampoeng seuneubok punti. Penelitian dilaksanakan pada bulan juni 2019- juli 2019

2. Subjek dan Objek Penelitian

Subjek dalam penelitian ini adalah guru dan anak TK Rahmad Damai Aceh Kecamatan Peureulak Timur Kabupaten Aceh Timur, sedangkan yang menjadi objek peneliti adalah Pembelajaran Audio Visual Dalam Mengembangkan Bahasa Anak Dalam Membaca Al-Qur'an anak Kelompok B TK Rahmad Damai Aceh

1. Populasi Dan Sampel Penelitian

Populasi adalah seluruh data yang menjadi pwerhatian peneliti dalam suatu ruang lingkup, dan waktu yang sudah ditentukan. Dalam penelitian ini ditentukan subjek sebagai sumber data yang relevan dengan masalah yang diteliti untuk dipelajari dan di tarik kesimpulannya. Sampel merupakan populasi atau subjek yang dipilih dan ditetapkan sebagai sumber data atau sumber informasi dari penelitian. pengambilan sampel dilakukan dengan teknik purposive sampling yang artinya adalah teknik penentuan sampel dengan pertimbangan tertentu.

Populasi penelitian ini berjumlah 37 orang anak di TK Rahmad Damai Aceh Pereulak Timur. Sampel dalam penelitian ini adalah anak kelompok B TK Rahmad Damai Aceh yang terdiri dari satu kelas B1 berjumlah 19 orang yang dijadikan 10 anak sebagai kelas kontrol dan 18 lagi sebagai kelas eksperimen.

2. Teknik pengumpulan Data

1) Observasi

Observasi digunakan peneliti sebagai teknik pengumpulan data yang meliputi kegiatan pengamatan untuk memperoleh data tentang keadaan sekolah dan kegiatan pembelajaran yang ada di TK Rahmad Damai Aceh

2) Wawancara

Wawancara adalah percakapan dua pihak antara pewawancara dan yang diwawancarai. Metode ini digunakan peneliti untuk mencari informasi tentang sejarah latar belakang berdirinya 
TK Rahmad Damai Aceh bangun tapan yogyakart, kondisidaan kendala yang dihadapi oleh guru dalam melaksanakan kegiatan pembelajaran TK Rahmad Damai Aceh bangun tapan yogyakarta

3) Dokumentasi

Suharsimi Arikunto berpendapat dokumentasi yaitu mencari data mengenai variabel berupa catatan, transkip, buku, surat kabar, majalah prasati, notulen rapat, leger, agenda, dan sebagainya. Jadi dokumentasi adalah suatu cara memperoleh data atau keterangan- keterangan melalui dokumen- dokumen.

Penulis menggunakan teknik ini sebagai alat untuk memperoleh data tentang sejarah berdirinya sekolah, daftar guru, daftar anak, daftar tenaga administrasi, dokumentasi penilaian anak tentang permulaan membaca, Media Audio Visual, juga untuk menggali data mengenai masalah yang sedang diteliti.

\section{Teknik Analisa Data}

Data adalah bahan mentah yang mempengaruhi diolah sehingga menghasilkan informasi atau kerangka, baik kualitatif maupun kuantitatif. Dalam penelitian ini, untuk menganalisis data digunakan model interactif yang dikembangkan oleh Miles dan Huberman yang dimulai dengan pengumpulan data, reduksi data, penyajian data, dan penarikan kesimpulan/ verifikasi. Proses analisis data.

Dilakukan secara terus menerus didalam proses pengumpulan data selama penelitian berlangsung.

a) Pengumpulan data

Kegiatan ini adalah merupakan aktivitas mengumpulkan data dengan baik cara yang telah dilakukan melalui observasi, wawancara maupun dokumentasi. Dalam hal ini data yang dikumpulkan masih sangat kasar, sebelum tersusun sehingga nantinya perlu dipilah kembali. Pada proses ini, semua data yang terkait dengan masalah penelitian, yang tentang bagaimana pembelajaran Media Audio Visual untuk perkembangan kongnitif dan bahasa anak di TK Rahmad damai aceh .

b) Reduksi data

Menurut Milles dan Huberman, reduksi data merupakan suatu kegiatan proses pemilihaan, pemusatan perhatian pada penyederhanaan, pengabstrakan dan transformasi data mentah yang di dapat dari catatan- catatan yang tertulis di lapangan. Data yang terkumpul dari observasi, wawancara, dan dokumentasi sangat banyak dan kompleks, serta masih tercampur, sehingga perlu dipilih hal- hal yang pokok dan disusun secara sistematis. Data yang dianggap relevan dan penting adalah yang berkaitan dengan pembelajaran Media Audio Visual untuk perkembangan kongnitif dan bahasa anak di rahmad damai aceh. 
c) Display data

Display dataadalah kegiatan menyajikan data ini/ pokok, sehingga dapat memberikan gambaran yang lebih jelas dan tajam mengenai hasil pengantar, wawancara sertadokumentasi. Display data dalam penelitian ini dengan cara menyajikan data ini/ pokok yang mencakup keseluruhan hasil penelitian, tanpa mengabaikan data- data pendukung, yaitu mencakup proses pemilihan, pemuatan penyederhanaan, dan transformasi data kasar yang diperoleh dari catatan lapangan.

Bentuk penyajia dataadalah teks naratif ( pengungkapan secara tertuli/kata kata). Hal ini sesuai dengan masalah penelitian yang diteliti yang bersifat deskriptif. Display data memiliki tujuan untuk memudahkan dalam mendeskripsikan suatu peristiwa, sehingga memudahkan untuk mengambil suatu kesimpulan.

d) Kesimpulan/ verifikasi

Kesimpulan dalam penelitian kualitatif merupakan temuan baru yang sebelumnya belum ada. Temuan dapat berupa deskripsi atau gambaran suatu objek yang sebelumnya masih remangremang atau gelap sehingga setelah diteliti menjadi jelas.

\section{HASIL DAN PEMBAHASAN}

Untuk mengetahui seberapa pengaruhnya media pembelajaran Audio Visual terhadap bahasa anak dalam membaca Al- Qur'an di TK Ramad Damai Aceh. Berdasarkan hasil didapat bahwa pengaruh yang diberikan pembelajaran media audio visual terhadap pengaruh bahasa anak dalam membaca al- qur'an di TK Rahmad Damai Aceh adalah Terdapat 2 katagori perolehan Hal ini disebabkan karena siswa tidak teliti dalam membaca Al- Qur'an .

Hasil Pedoman Wawancara

Tabel 4.3

Apakah Guru Telah Mengajarkan Ayat yang Dibaca Oleh Anak

\begin{tabular}{ccc}
\hline Alternatif & Frekuensi & Persentase $(\%)$ \\
Sudah & 32 & 86,48 \\
Belum & 5 & 13,53 \\
Jumlah & 37 & 100 \\
\hline
\end{tabular}

Berdasarkan Tabel 4.3 di atas, dapat diketahui bahwa 86,48 \% siswa menyatakan bahwa mereka sudah menerima ayat yang akan dibaca , 13,14 \% belum menerima ayat yang akan dibaca

Dengan demikian dapat ditarik kesimpulan bahwa hampir semua siswa telah menerima tugas untuk mendengarkan cara Baca Al-qur'am 
Tabel 4.4

Bagaimana Pendapat Anda Tentang Pembelajaran yang Telah Dilaksanakan Oleh Guru terhadap Ayat yang Akan Dibaca.

\begin{tabular}{ccc}
\hline Alternatif & Frekuensi & Persentase $(\%)$ \\
Mudah & 20 & 54,05 \\
Susah & 17 & 45,95 \\
Jumlah & 37 & 100 \\
\hline
\end{tabular}

Berdasarkan Tabel 4.4 di atas, dapat diketahui bahwa 54,05 \% siswa menyatakan bahwa mereka Mudah menerima ayat yang akan dibaca , 45,05\% susah menerima ayat yang akan dibaca

Dengan demikian dapat ditarik kesimpulan bahwa hampir semua siswa telah menerima ayat yang akan dibaca

\section{Tabel 4.5}

Bagaimana Kemampuan Anda dalam Menyelesaikan Pembacaan Ayat

\begin{tabular}{ccc}
\hline Alternatif & Frekuensi & Persentase $(\%)$ \\
Mudah & 23 & 62,16 \\
Susah & 14 & 37,84 \\
Jumlah & 37 & 100 \\
\hline
\end{tabular}

Berdasarkan Tabel 4.5 di atas, dapat diketahui bahwa 62,16 \% siswa menyatakan bahwa mereka mudah menerima ayat yang akan dibaca 37,84 \% susah menerima materi ayat yang akan dibaca .

Dengan demikian dapat ditarik kesimpulan bahwa hampir semua siswa telah menerima ayat yang akan dibaca .

Tabel 4.6

Menurut Anda Apakah Ada Kesulitan-kesulitan dalam Menyelesaikan Ayat yang Akan Dibaca

\begin{tabular}{ccc}
\hline Alternatif & Frekuensi & Persentase $(\%)$ \\
Tidak sulit & 25 & 67,57 \\
Sulit & 12 & 32,43 \\
Jumlah & 37 & 100 \\
\hline
\end{tabular}

Berdasarkan Tabel 4.4 di atas, dapat diketahui bahwa 67,57 \% siswa menyatakan bahwa mereka tidak sulit menerima ayat yang akan dibaca , 32,43\% sulit menerima ayat yang akan dibaca

Dengan demikian dapat ditarik kesimpulan bahwa hampir semua siswa telah menerima ayat yang akan dibaca 
Tabel 4.7

Bagaimanakah Pengetahuan Anda Tentang Materi Ayat yang Akan Dibaca

\begin{tabular}{ccc}
\hline Alternatif & Frekuensi & Persentase $(\%)$ \\
Mudah & 20 & 54,05 \\
Sulit & 17 & 45,95 \\
Jumlah & 37 & 100 \\
\hline
\end{tabular}

Berdasarkan Tabel 4.7 di atas, dapat diketahui bahwa 54,05 \% siswa menyatakan bahwa mereka sudah menerima ayat yang akan dibaca , 45,95\% belum menerima ayat yang akan dibaca

Dengan demikian dapat ditarik kesimpulan bahwa hampir semua siswa telah menerima ayat yang akan dibaca

Kemampuan siswa dalam mengenal dan memahami huruf hijayyah

Berdasarkan hasil penelitian siswa di kelas B1 dan B2 menunjukkan bahwa 3 orang siswa memperoleh hasil tes dengan kategori tinggi, kemudian 22 orang siswa memperoleh hasil tes dengan kategori cukup, dan 12 orang siswa memperoleh hasil tes dengan kategori rendah, dalam mengenal dan cara pada pada ayat. Seorang siswa disebut tuntas belajar bila memperoleh nilai sekurang-kurangnya 75 dari nilai ideal. Dalam suatu kelas siswa disebut tuntas belajar bila kelas tersebut terdapat sekurang-kurangnya $85 \%$ siswa yang tuntas.

a. Siswa kurang teliti

Pada saat mengalikan ataupun pembagian kebanyakan siswa kurang teliti, hal ini menyebabkan sebagaian siswa sulit dalam mengenal makrojal huruf dengan baik dan benar. Hal ini bukan karena siswa belum mampu mengenal dan membaca huruf, tetapi siswa kurang teliti pada saat membedakan yang benar dan yang salah, sehingga hasilnya salah. Siswa sering melakukan kesalahan kalkulasi dalam cara baca siswa yang tentunya mempengaruhi hasil akhir jawaban.

b. Kurangnya perhatian dan bimbingan orang tua

Perhatian dan bimbingan dari orang tua dan orang-orang terdekat sangat dibutuhkan. Dikarenakan hal tersebut akan menambah semangat siswa dalam belajar. Sehingga apabila anak mengalami kesulitan, anak tidak tahu bertanya kepada siapa. Sehingga mengakibatkan anak malas untuk belajar yang mengakibatkan kemampuan siswa rendah.

Upaya-upaya yang dilakukan guru dalam meningkatkan kemampuan siswa dalam Kemampuan siswa dalam menyelesaikan bacaan nya terhadap ayat 
Berdasarkan hasil penelitian siswa di kelas B1 dan B2menunjukkan bahwa 3 orang siswa memperoleh hasil tes dengan kategori tinggi, kemudian 22 orang siswa memperoleh hasil tes dengan kategori cukup, dan 12 orang siswa memperoleh hasil tes dengan kategori rendah, dalam memahami dan mendengar cara baca pada ayat yang akan dibaca Seorang siswa disebut tuntas belajar bila memperoleh nilai sekurang-kurangnya 75 dari nilai ideal. Dalam suatu kelas siswa disebut tuntas belajar bila kelas tersebut terdapat sekurang-kurangnya $85 \%$ siswa yang tuntas.

c. Siswa kurang teliti

Pada saat mengalikan ataupun pembagian kebanyakan siswa kurang teliti, hal ini menyebabkan sebagaian siswa sulit dalam memahami dan mengenal huruf dengan baik dan benar. Hal ini bukan karena siswa belum mampu mengenal makrijol huruf, tetapi siswa kurang teliti pada saat membedakan yang benar dan yang salah, sehingga hasilnya salah. Siswa sering melakukan kesalahan kalkulasi dalam jawaban siswa yang tentunya mempengaruhi hasil akhir jawaban.

d. Kurangnya perhatian dan bimbingan orang tua

Perhatian dan bimbingan dari orang tua dan orang-orang terdekat sangat dibutuhkan. Dikarenakan hal tersebut akan menambah semangat siswa dalam belajar. Sehingga apabila anak mengalami kesulitan, anak tidak tahu bertanya kepada siapa. Sehingga mengakibatkan anak malas untuk belajar yang mengakibatkan kemampuan siswa rendah.

Upaya-upaya yang dilakukan guru dalam meningkatkan kemampuan siswa dalam mengenal huruf- huruf al- qur'an

Upaya-upaya yang dapat dilakukan oleh guru matematika yaitu guru berinteraksi dan melakukan tanya jawab dengan siswa, mengulang pelajaran dan memberikan remedial.

1. Berinteraksi dan melakukan tanya jawab dengan siswa

Guru berinteraksi dan melakukan tanya jawab dengan siswa guna untuk mengetahui penyebab siswa belum mampu dalam mengenal huruf. Dengan tanya jawab yang dilakukan guru, guru akan mengetahui penyebabnya sehingga akan lebih mudah untuk mencari solusinya.

2. Mengulang pelajaran

Adapun salah satu solusi yang dilakukan guru ialah menjelaskan kembali materi yang dianggap sulit oleh siswa. Dengan mengulang pelajaran, diharapkan agar siswa mampu dalam mengenal huruf Melakukan remedial 
Upaya selanjutnya yang ditempuh oleh guru setelah memberi penjelasan yaitu memberikan remedial. Hal ini bertujuan untuk mengetahui sejauh mana tingkat keberhasilan yang dicapai oleh siswa setelah dilakukan penjelasan ulang dan remedial.

Upaya-upaya yang dapat dilakukan oleh guru di kelas yaitu guru berinteraksi dan melakukan tanya jawab dengan siswa, mengulang pelajaran dan memberikan remedial.

3. Berinteraksi dan melakukan tanya jawab dengan siswa

Guru berinteraksi dan melakukan tanya jawab dengan siswa guna untuk mengetahui penyebab siswa belum mampu dalam mengenal huruf- huruf hijayyah. Dengan tanya jawab yang dilakukan guru, guru akan mengetahui penyebabnya sehingga akan lebih mudah untuk mencari solusinya.

4. Mengulang pelajaran

Adapun salah satu solusi yang dilakukan guru ialah menjelaskan kembali materi yang dianggap sulit oleh siswa. Dengan mengulang pelajaran, diharapkan agar siswa mampu mengenal dan memahami cara baca Al-Qur'an

5. Melakukan remedial

Upaya selanjutnya yang ditempuh oleh guru setelah memberi penjelasan yaitu memberikan remedial. Hal ini bertujuan untuk mengetahui sejauh mana tingkat keberhasilan yang dicapai oleh siswa setelah dilakukan penjelasan ulang dan remedial.

\section{DAFTAR PUSTAKA}

Busthomi. Panduan Lengkap PAUD Melejitkan Potensi Dan Kecerdasan Anak Usia Dini. Jakarta: Citra Publishing 2012

Djamarah, Syaiful Bahri. Pola asuh orang tua dan komunikasi dalam keluarga: membangun cintra membentuk pribadi anak. Jakarta : Rineka Cipta

Dokumen TK Rahmad Damai Aceh Timur, 2018/2019.

H. Hamruni. (2008). Konsep Edutainment Dalam Pendidikan Islam. Bidang Akademik:Yogyakarta 2008

Isjono. (2011). Model Pembelajaran Anak Usia Dini.( Bandung : alfabeta, cetakan ke 3)

Jasmani, Julia. (2007). Panduan prakti mengajar berbasis Multiple Intelligences. Nuansa Bandung:

Kementrian Pendidikan Nasional RI Direktorat Jendral Manajemen Dasar Dan Menengah Direktorat Pembinaan TK Dan SD, Peraturan Menteri Pendidikan Dan Kebudayaan Republic Indonesia Nomor 137 Tahun 2014 tentang standar pendidikan Anak Usia Dini

Khadijah. (2016). Perkembangan kongnitif anak usia dini. Medan: perdana publishing. 
Permendikbud No 137 tahun 2014 tentang standar nasional pendidikan anak usia dini

Munib, Achmad. (2012) Pengantar Ilmu Pendidikan. Semarang: UPT UNNES Press

Ngalimun. (2012) Strategi dan Model Pembelajaran. Yogyakarta: Aswaja Pressindo.

Ramadhani, Aqmarina. (2017) Pengaruh Pembelajaran SAVI. Jurnal Model Pembelajaran, Volume 1, Nomor, 8.

Saputra, Fatimah, Khadijah, Edi. (2011). Pengaruh Media Audio Visual Terhadap Kecerdasan Interpersonal Dan Intrapersonal Anak Usia Dini (5-6 Tahun) Di Raudhatul Athfal Hafizh. Jurnal kecerdasan interpersonal, volume 2, nomor 2 Tahun 2011

Sirega, Sarmaida r. tentang pengaruh model Audio Visual terhadap tingkat pengetahuan dan sikap remaja tentang bahaya merokok di SMP Negeri 2 Kecamatan Halongonan Timur Kabupaten Padang Lawas Utara.( tesis Pascasarjana Universitas Sumatra Utara)

tentang pengaruh model Audio Visual terhadap tingkat pengetahuan dan sikap remaja tentang bahaya merokok di SMP Negeri 2 Kecamatan Halongonan Timur Kabupaten Padang Lawas Utara.( tesis Pascasarjana Universitas Sumatra Utara)

Slameto. (2010). Belajar Dan Faktor-Faktor Yang Mempengaruhinya. Jakarta: Rineka cipta.

Sugiyono. (2010) Metode penelitian kuantitatif kualitatif dan R\&D. Bandung: Alfabeta.

Sujana, Cristine. (2008). Cara mengembangkan berbagai komponen kecerdasan. Jakarta: indeks

Sujiono, yuliani Nuraini dan sujiono. (2010). Bandung, bermain kreatif berbasis kecerdasan jamak. Jakarta: indeks

Suparno, Paul. (2004). Teori inteligensi ganda. Yogyakarta: Kanisius.

Susilo, M. Joko. (2006). Gaya Belajar Menjadikan Lebih Pintar. Yogyakarta: Pinus 2006

Suyadi. (2010). Psikologi Belajar PAUD. (yogyakarta: PEDAGOGIA).

Trianto. (2007). Model- model pembelajaran inovatif berorientasi konstruktivistik. Jakarta: prestasi pustaka. 